\title{
2012 年日本地理学会秋季学術大会および秋季代議員会記録
}

\author{
（於 神戸大学鶴甲第 1 キャンパス)
}

\section{2 年秋季代議員会記事}

2012 年度第 1 回代議員会は, 2012 年 10 月 6 日 （土） 10 時 30 分〜11 時 30 分, 神戸大学鶴甲第 1 キャンパス K 棟 K202 室にて開催された。山下総務 専門委員長の開会の辞, 矢ケ崎会長の挨拶, 山崎大 会実行委員長の会場校挨拶があった，次に香川代議 員を議長に選出し，久木元総務専門委員に書記を委 託した。 山下総務専門委員長より, 総会の成立が承 認された（出席 48 名，委任状 55 , 合計 103 名).

\section{I. 報告事項}

1. 通常会務報告

荒井理事長より，専門委員会の活動実績ならびに 今後の活動予定が説明された，公益社団法人 2012 年度定時総会, 会員ご逝去にともなう役員補充, 新 規事業（「小林浩二研究助成」, 英文叢書の刊行）に 関する進渉状況が報告された。続いて, 総務専門委 員会, 財務専門委員会, 3 種の編集専門委員会, 集 会専門委員会, 広報専門委員会, 交流専門委員会, 企画専門委員会, 地理教育専門委員会, 資格専門委 員会の各活動が説明された。

その他, 今後の検討課題として, 公益社団法人化 にともなう各種対応（新会計システム，予算管理体 制, 情報公開体制)，事務局体制の整備（会員・財務 データの保全）について説明された。

2. 財務状況について

箸本財務専門委員長より, 資料 1 に基づいて財務 関連の報告が行われた。

3. 平成 24 年度 GIS 学術士等·地域調査士等の認 定について

荒井理事長，鈴木資格専門委員長より，資料 2 に 基づいて次の報告がなされた。

4 月中旬に GIS 学術士資格専門委員会事務を資格 専門委員会へ引継ぎ, 9 月 29 日に第 1 回 GIS 学術士 資格委員会が開催され，10月の常任理事会で GIS 学
術士等が認定される予定である

地域調査士認定委員会の実施 (4月，6月，9月の 3 回), 専門地域調査士 (申請 13 名, 認定 10 名), 地 域調査士（申請 34 名, 認定 32 名), 地域調査士（見 込み) 証明書の発行 1 名, 講習会受講者数（地域調 查士 114 名 (4月), 専門地域調查士 16 名 (6月), 国士舘大学), 今後の講習会, 認定委員会の予定につ いて報告された。

GIS 学術士制度規程類の見直しの進捗状況につい て報告され, 改正案については 2013 年春季学術大 会代議員会に扔いて説明される予定である.

\section{II. その他}

1. 2013 年京都国際地理学会議組織委員会からの 報告

石川義孝会員（京都国際地理学会議組織委員会委 員長), 秋山会員 (京都国際地理学会議募金委員会委 員長）より, 配付資料にもとづき, 京都国際地理学 会議に向けた進渉状況および寄付・募金の方法につ いて説明された。

2. 国際地理オリンピック実行委員会からの報告 井田実行委員長より, 配付資料にもとづき, ドイ ッ・ケルンに扔ける国際地理オリンピックへの参加 および結果について説明された（銅メダル1名).

京都大会にむけた要綱・予算・スケジュール等の 作成状況が報告された。

3. その他

山下総務専門委員長より, 出席者数の修正が行わ れた。

以上で議事を終了して，香川議長による書記の解 任と議長の解任が行われた後, 山下総務専門委員長 の閉会の辞をもって, 2012 年度第 1 回代議員会は終 アした。

\section{出版助成委員 会答申}

出版助成委員会
日本地理学会では, 2010 年度から地理学研究の振 興と社会への貢献を目的として, 出版助成制度を開 
始させた，今年度はその 3 年目にあたる。今年度よ り 2012 年 6 月 1 日から 6 月 30 日を申請期間として 地理学に関する学術図書の公募を行った。そ結 果, 3 件（全部が和書で, うち 1 編が訳書, 3 件とも 共編著）応募があり，いずれも興味深い力作であっ た。

7 名の委員 (阿部和俊 - 関戸明子 - 高田将志 $\cdot$ 中 川清隆・野中健一・野間晴雄・橋本雄一) により構 成された出版助成委員会は, 慎重に審議した結果, 9 月 5 日付で出版助成候補として, 以下の 2 冊を日本 地理学会理事長に答申した。

\section{交付認定者：土屋 純会員}

土屋 純・兼子 純 編著『小商圈時代の流通シス テム』(古今書院)

本書は日本の流通システムの適応戦略や新たな展 開を把握し，今後の流通システムのあり方を実証的 にとらえることを目的としている，量販型流通シス テムの再編成, 小規模流通システムの台頭, 流通と まちづくりとの関係も取り上げられている。近年,

流通システムの変革は著しいものがあり, 人文地理 学の分野においても研究が増えている. 本書は今後 の流通システムのあり方を地理学的に実証的にとら えることをも目的としている，優れた成果物として 評価される。

\section{交付認定者：松原 宏会員}

松原宏編著『日本のクラスター政策と地域イノ ベーション』(東京大学出版会)

本書は地域イノベーション研究を人文地理学分野 に扔ける新しい潮流の一つとすることを主目的とし たものである. 理論的な検討の後に, マクロ分析と して日本のクラスター政策に関する分析を行い, ミ クロ分析として, 仙台地域・福岡地域・浜松地域· 宇部地域・長野県・山形県・茨城県が取り上げられ ている. 現代の社会にとって重要なキーワードであ る「知識」を分析の中心に据え, 近年の日本におけ る政策と地域の取組みとの関係を論じている。理論 研究と実証研究のバランスもよい，優れた成果物と して評価される。

\section{学 術大会記 事}

2012 年秋季学術大会は, 10 月 6 日（土）～9 日 (火) に神戸大学鶴甲第 1 キャンパスを中心に開催さ れ, 有料参加者 587 名（正会員 421 名, 学生会費納 入正会員 70 名, 非会員 96 名), 名誉会員 - 交付認定 者等の参加があった。

学術研究発表は 10 月 6 日（土）・7日（日）の両 日に8 会場で一般発表（ポスター発表を含み, 130 件）と, 計 45 件の発表を含む八つのシンポジウムが 行われた。シンポジウムは 6 日に「いま改めて二つ の大震災から学ぶ- 一阪神淡路大震災・東日本大震 災と地理学・変動地形学—」(二つの大震災につ いて「予測可能性」を厳しく見直し, 原発と活断層 の問題にも焦点を当て, 低頻度巨大災害の想定のあ り方を議論した，参加者 210 名)，7 日に「幕末蝦夷 地陣屋の景観復原に向けて」(絵図資料の収集 - 分 析による基礎研究の成果を踏まえて, 自然環境（地 形・気候）の分析や，歴史 GIS 手法㧍よび建築学の 建物復元の手法も駆使して, 当時の景観を総合的に 視覚化する共同研究の中間成果を発表した，参加者 約 30 名).「日本の山村の非限界性と存立基盤— 山村振興への地理学的視点の考察—」(限界化が 進む日本の山村の非限界的側面を多面的に分析．参 加者約 80 名).「大学地理教育の質保証に関する教
育課程編成上の参照基準の在り方」(作成中の大学 教育に扔ける質保証・教育課程編成上の「地理学」 参照基準の最終まとめ前原案を学会員に示し, 広沉 な意見を聴取した，参加者約 100 名).「脱成長社会 の日本の三大都市圈の変容」(東京圈と京阪神圈の 通勤流動, コーホート別人口分布の変動, 高齢化の 進行状況などを 2010 年国勢調查の結果も含めて検 証し, 都心回帰㧍よび郊外化の終焉, 通勤流動のモ ザイク化，進行する郊外住宅地での高齢化現象さら には 2010 年国調の不詳人口の急増の問題点につい て討議した。参加者 120 名).「ゾドと遊牧知——乾 燥地災害学の体系化に向けて—」（中央ユーラシ アの乾燥で寒冷という厳しい環境下で発生する自然 災害の特徵とそれへの遊牧の対応についてさまざま な視点から議論した，参加者約 70 名),「ジオパー クに生じた諸問題——持続可能なシステムの構築に 向けて一」（自然環境資源の保全と活用を目的と した諸制度とジオパークを比較し、ジオパーク活動 の持続可能性について議論がなされた，参加者約 50 名).「阪神淡路大震災地域の復興の時空間分析 とマイクロジオデータの利活用」(マイクロジオ デー夕は, 建物 1 棟単位や人間一人単位のミクロな 時空間データである。、イクロジオデータの特性, 
その有用性について論議した. 参加者 35 名）が行 われた。

10 月 6 日には, 地理教育公開講座「地理教育に抒 けるフィールドワークの活用」が開催され，懇親会 は生協食堂に打いて，199名が参加する盛会であっ た。

また，7日には各研究グループの集会が行われ た.

10 月 8 日（月）には, 巡検第 1 班「いなみ野台地 一一過去, 現在, 未来一」（案内者 5 名を含み参加 者 37 名)，第 3 班「神戸の中国文化を巡る」(案内者
3 名を含み参加者 20 名）, 8 日（月）・9日（火）に は, 第 2 班「山陰海岸ジオパーク—日本海形成に 伴う多様な地形・地質 ·風土と人々の暮らし—」 (案内者 2 名を含み参加者 12 名) が実施され, 有意 義な現地討論がなされた。

山崎 健実行委員長はじめ大会役員㧍よび神戸大 学の学生諸君には, 多大な御協力をいただいたこと に深く感謝の意を表するものである。最後に各会場 で座長の労をとられた会員, 巡検案内にあたられた 会員の行き届いた準備にたいして心から打礼を申し 上げる. 